\title{
Befogókészülék fejlesztése koponyaűri áramlásirányító sztentek húzóvizsgálatához
}

\section{Development of a Clamping Device for Tensile Testing of Intracranial Flow Diverter Stents}

\author{
Bukor Csongor, ${ }^{1}$ Károly Dóra, ${ }^{2}$ Csippa Benjamin ${ }^{3}$ \\ ${ }^{1}$ Budapesti Müszaki és Gazdaságtudományi Egyetem, Gépészmérnöki Kar, Anyagtudomány és Technológia \\ Tanszék, Budapest, Magyarország, bukorcsongor@edu.bme.hu \\ 2 Budapesti Müszaki és Gazdaságtudományi Egyetem, Gépészmérnöki Kar, Anyagtudomány és Technológia \\ Tanszék, Budapest, Magyarország, kdora@eik.bme.hu \\ ${ }^{3}$ Budapesti Müszaki és Gazdaságtudományi Egyetem, Gépészmérnöki Kar, Hidrodinamikai Rendszerek \\ Tanszék, Budapest, Magyarország, bcsippa@hds.bme.hu
}

\begin{abstract}
The main danger of a brain aneurysm (a sack-like bulge on the vessel wall) is that in the event of a rupture a severe hemorrhage can occur which may cause death. However, if doctors have tools at their disposal, such as numerical models and simulations for analyzing patient-specific blood vessels, they could use them to decide if a particular treatment is necessary and if so, when. For such models, the different mechanical characteristics of the flow control devices are the input data. Several of these mechanical properties of the devices, such as modulus of elasticity and tensile strength, are determined by tensile testing. In the course of our research, we have developed a clamping device suitable for uniaxial tensile testing of flow diverter stents.
\end{abstract}

Keywords: uniaxial tensile testing, mechanical properties, clamping device.

\section{Összefoglalás}

Az aneurizmák (értágulatok) legfőbb veszélyét az jelenti, hogy az érfalra ható igénybevételek miatt kirepedhetnek, ezáltal súlyos belső vérzést, halált okozhatnak. Ha azonban az orvosnak rendelkezésére állnak olyan mérnöki eszközök, mint például az artériák elemzésére alkalmas numerikus modellek, szimulációk, ezek segítségével el lehet dönteni, hogy egy adott értágulatnál szükséges-e a beavatkozás, és amennyiben igen, mikor. Az ilyen modellekhez az áramlásirányító eszközök mechanikai jellemzői bemeneti adatok. Több ilyen mechanikai tulajdonság, például a rugalmassági modulusz és a szakítószilárdság meghatározása szakítóvizsgálattal történik. Kutatásaink során ilyen eszközök egytengelyű húzóvizsgálatára is alkalmas befogókészüléket fejlesztettünk, több méretben, a különböző érátmérőkhöz tartozó sztentekhez.

Kulcsszavak: szakítóvizsgálat, mechanikai tulajdonságok, befogókészülék.

\section{Bevezetés}

A verőerek tágulatainak, az ún. aneurizmáknak egyik legnagyobb veszélye az elvékonyodott érfal megrepedése következtében kialakuló vérzés, amelynek szövődményeiben a betegek kb. 15\%-a meghal, mielőtt a kórházba érne [1].

A koponyaüri értágulatok kezelésére többek között olyan, hálós szerkezetü, biokompatibilis eszközöket, áramlásirányító sztenteket - a továbbiakban ezeket sztentnek nevezzük - használnak, amelyek áramlásmódosító, -irányító hatást fejtenek ki a sérült érszakaszon, így csökkentve az érfalra jutó nyomást, amit a vér áramlása okoz, ezáltal megalvasztva a vért az aneurizmazsákban $[2,3]$. 
Az ilyen sztentek fő hemodinamikai hatása a véráramlás irányítása és lassítása az aneurizmában. Az érszakasz és az értágulat között megváltoztatva a dinamikus folyadékcserét, olyan hemodinamikai, intraaneurizmás környezetet hoznak létre, amely elősegíti az aneurizmazsákon belüli trombózis kialakulását [4, 5].

Egy szimuláció végeredményének megbízhatóságát nagyban befolyásolja a bemeneti adatok pontossága. A minták ideális vizsgálati módja a valós élettani feltételek között, vagyis a saját környezetükben történő, azaz in vivo vizsgálat. Azonban ez invazív mivolta és etikai szempontok miatt nem alkalmazható. Helyette az adott érszakasz vizsgálatára csak a valós peremfeltételeket megközelítő, in vitro vizsgálat jöhet számításba [6].

Kutatásunk célja bemeneti adatokat szolgáltatni egy olyan mechanikai modellhez, amellyel szimulálható az áramlásirányító sztentek feltágítása egy konkrét beteghez tartozó aneurizmamodellben. A sztentmodellben a szálakat a szálak keresztezésénél csatlakozó felületi rugókra cserélik, és kiegészül a modell radiális irányban álló, fiktív rugókkal. A mechanikai tulajdonságokat a két különböző rugótípuson keresztül modellezik, eltérő rugóállandókkal [7]. Az egyik ábrázolja a felületi mechanikát (pl. a hosszmenti összehúzódás), míg a másik a radiális irányú tágulás modellezéséhez szükséges. Ehhez szükség van a sztentek húzóvizsgálatára és a vizsgálat közben az átmérőváltozás detektálására.

\section{Felhasznált anyagok és mérési mód- szerek}

\section{1. Áramlásirányító sztentek}

$\mathrm{Az}$ 1. ábrán látható két sztent befoglaló méretei az 1. táblázatban láthatók. Az egyik vizsgált áramlásirányító sztent Ni-Ti ötvözetből, a másik Co-Cr ötvözetből készült. A gyártó azt a hosszméretet írja a dobozra, amelyet egy konstans át-

1. táblázat. A felhasznált áramlásirányító sztentek adatai

\begin{tabular}{|l|r|r|}
\hline \multicolumn{1}{|c|}{ Jel } & \multicolumn{1}{c|}{$\begin{array}{c}\text { Ni-Ti } \\
\text { sztent }\end{array}$} & $\begin{array}{c}\text { Co-Cr } \\
\text { sztent }\end{array}$ \\
\hline Névleges átmérő (mm) & 5 & 5 \\
\hline Gyártói ajánlott hossz (mm) & 24 & 20 \\
\hline Tömeg (mg) & 25,5 & 29,9 \\
\hline \multirow{2}{*}{ Átmérő (mm) } & 5,22 & 5,22 \\
$\pm 0,019$ & $\pm 0,034$ \\
\hline Hosszúság (mm) & 11,63 & 12,75 \\
& $\pm 0,070$ & $\pm 0,0391$ \\
\hline
\end{tabular}

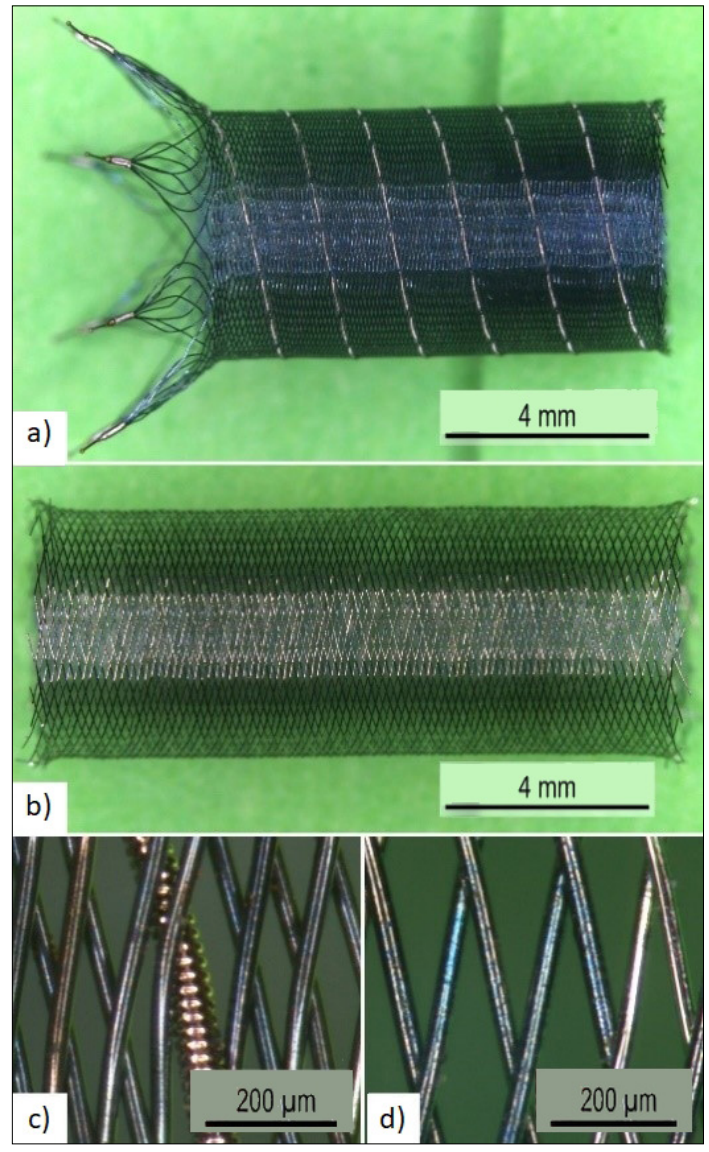

1. ábra. A Ni-Ti sztent (a), a Co-Cr sztent (b) teljes egésze, a Ni-Ti sztent bordái (c) és a Co-Cr sztent bordái (d)

mérőjü érszakaszmodellben venne fel a sztent tökéletes körülmények között. A gyártói hossz általában más, mint a feltágítás utáni értékek, mivel az operáló orvos általi manuális beavatkozás befolyásolhatja a sztent elhelyezkedését. A mért átmérőértékek szabad, feszültségmentes állapotban nagyobbak, mint a gyártó által megadott, névleges átmérő. $\mathrm{Az} 1 \mathrm{c}$ ) ábrán látható Ni-Ti sztentnél egyértelműen látszik a szövésben 15 db, hosszanti bordánként elhelyezett markerszál, amelyeket keresztbe, két-két szomszédos szál alá és fölé szőnek a szerkezetbe. A Co-Cr sztentnél ilyen markerszál nem figyelhető meg.

\subsection{A befogókészülék tervezése}

A szakítóvizsgálat szempontjából a berendezésen kívül sarkalatos pont a megfelelő befogókialakítás. A mi esetünkben ez kiemelkedő szerepet kap, mivel a vizsgált minták nagyon könnyen károsodnak. 
A befogó tervezése során az alábbi szempontokat vettük figyelembe. Elsősorban kellően nagy szorítóerőt kell kifejtenie, hogy megakadályozza a sztent megcsúszását. Ezt az erőt a kerület mentén kis felületen kell átadni a sztentre az egyenletes alakváltozás és a befogási hossz egyértelmű meghatározhatósága érdekében, illetve biztosítani kell, hogy a szorítóerő a lehető legkisebb mértékben deformálja a sztentet. Ezenkívül a befogónak kis tömegünek kell lennie, és lehetővé kell tennie azt, hogy kézi erővel gyorsan és pontosan be tudjuk vele fogni a sztentet. Végezetül célunk volt az egyszerű és kötséghatékony gyárthatóság, illetve beszerezhetőség is.

Eleinte egy rendkívül egyszerü konstrukciót alkalmaztunk. A sztent két végét egy-egy szilikonnal borított tengelyre húztuk, és kívülről egy-egy gyorskötöző segítségével kialakítottuk a szorítóerőt a sztent két végén. A gyorskötöző alá a sztent sérülésének elkerülése érdekében szintén vékony szilikonborítást tettünk. A húzóvizsgálathoz a két tengelyt fogtuk be a szakítógépbe. Ezzel a megoldással csak lassan és pontatlanul lehetett befogni a sztenteket, illetve a befogási hossz meghatározása is nehézkes volt. Ez a probléma a 2. ábrán látható befogókészülék megtervezéséhez vezetett. Az új konstrukcióban a befogórúdra húzzuk rá a sztentet, kívülről pedig a csap körül elforduló két szorítószár közé fogjuk be. A befogás helyén egy O-gyürü viszi át az erőt. A szárak végén egy-egy barázda lehetővé teszi, hogy egy gumigyưrűvel kialakítsuk a szorítóerőt. A befogót Formlabs Form 2 berendezéssel, additív gyártással gyártottuk le.

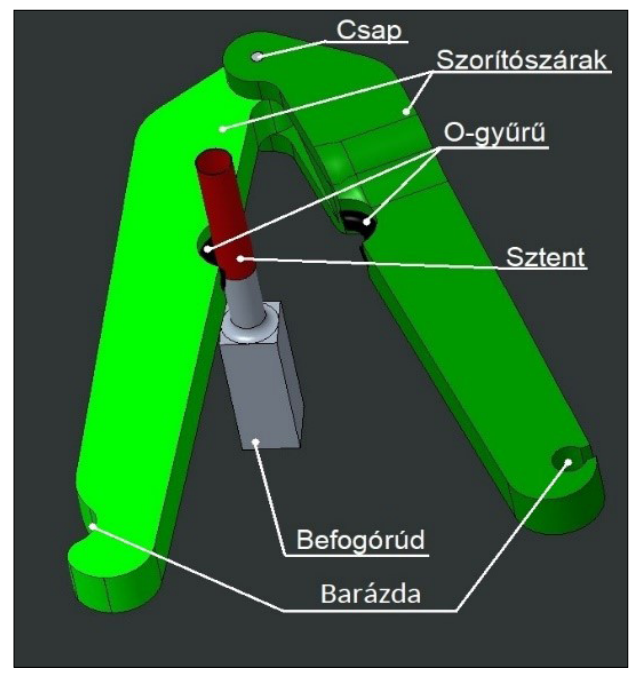

2. ábra. A befogó szerkezeti modellje

\subsection{Mérési módszer}

A húzóvizsgálatokat INSTRON 5965 típusú, elektromechanikus anyagvizsgáló berendezéssel végeztük, amelyhez rendelkezésre áll egy $\pm 5 \mathrm{~N}$ méréshatárú erőmérő cella, és egy hozzá tartozó, szintén $5 \mathrm{~N}$ terhelhetőségü, pneumatikus befogó, így nagyon pontos méréseket tudtunk végezni ebben a kis erőtartományban is. A mérést $10 \mathrm{~mm}$ keresztfej-elmozdulásig folytattuk, $6 \mathrm{~mm} / \mathrm{min}$ keresztfej-elmozdulási sebességgel.

A sztent axiális irányú húzása közben létrejövő átmérőcsökkenést fényképezőgéppel detektáltuk, a mérés kezdetétől 1 s időközönként készítve fényképet a mérés végezetéig. Így lett pontosan látható és mérhető a sztentek átmérőjének csökkenése. Az átmérőket a befogófejek közt félúton mértük le, és ebből számoltuk ki az átmérőváltozást.

\section{Eredmények}

A vizsgálat során a 3 . ábrán látható görbéket kaptuk, amelyeken jól látható a szignifikáns különbség a Ni-Ti és a Co-Cr sztent viselkedése között. A Ni-Ti sztent átmérőváltozásához és nyúlásához nagyobb erőre van szükség, mint a $\mathrm{Co}-\mathrm{Cr}$ sztentnél. A Ni-Ti ötvözet anyagú sztent 50\%-os

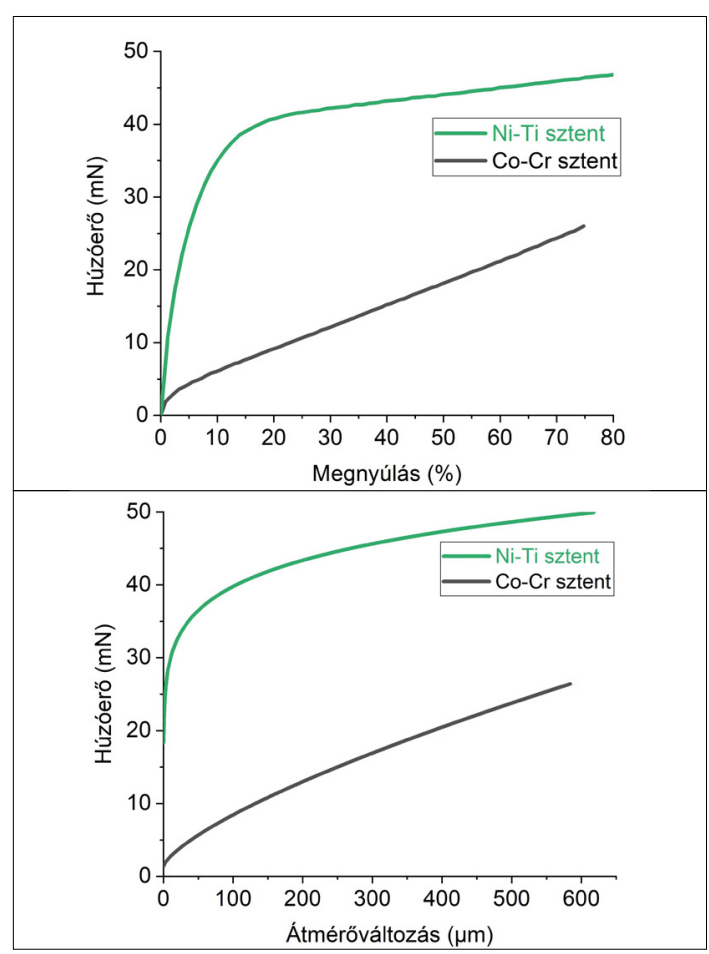

3. ábra. A Ni-Ti és a Co-Cr sztent húzóvizsgálatának eredménye, felül: erőmegnyújtás diagram, alul erö-átmérőváltozás diagram 
nyúlásához több mint kétszer akkora erőre van szükség, mint a Co-Cr ötvözet anyagú sztentnél. A 3. ábrán látható húzóerő-átmérőváltozás görbe kezdeti (függőleges) szakasza mutatja azt a részt, amikor a sztentek az erő növekedése mellett nem reagálnak átmérőváltozással, ebből lehet következtetni a mechanikai modellben a sztentek palástfelületén levő rugalmas elemek rugóállandóira, a görbe befejező szakaszából pedig a radiális irányú rugók viselkedésére tudunk következtetni [7].

\section{Következtetések}

A tervezett befogó és a mérési módszer alkalmas a koponyaűri áramlásirányító sztentek húzóvizsgálatára.

A vizsgálat eredményeként megállapítható, hogy a Ni-Ti ötvözet alapanyagú sztent ugyanakkora mértékű megnyújtásához nagyobb erőre van szükség, mint a Co-Cr ötvözet anyagú sztentnek.

A kutatás folytatásaként a befogó segítségével többféle áramlásirányító sztent húzóvizsgálatát fogjuk elvégezni, és az eredmények alapján a már említett modellt pontosítani. Ezenkívül a mérés segítségével új, sztentekhez hasonló geometriával rendelkező eszközök minősítése is lehetséges, amelyek szintén integrálhatók a teljes mechanikai modellbe.

\section{Köszönetnyilvánítás}

A publikáció az Innovációs és Technológiai Minisztérium NTP-SZKOLL-20-0067 kódszámú Nemzeti Tehetség Program, illetve a 2017-1.2.1-NAP-2017-00002 Nemzeti Agykutatási Program támogatásával valósult meg, valamint a kutatást támogatta az NKFIH Alap (TKP2020 IES, tsz: BME-IE-NAT; TKP2020 NC, tsz: BME-NCS) az Innovációs és Technológiai Minisztérium vezetése alatt.

\section{Szakirodalmi hivatkozások}

[1] Chalouhi N., Hoh B.L., Hasan D.: Review of cerebral aneurysm formation, growth and rupture. Stroke, 44/12. (2013) 3613-3622. http://doi.org/10.1161/STROKEAHA.113.002390

[2] Szikora I., Berentei Z., Kulcsar Z., Marosfoi M., Vajda Z. S., Lee W., Berez A., Nelson P. K.: Treatment of intracranial aneurysms by functional reconstruction of the parent artery: the Budapest experience with the pipeline embolization device. American Journal of Neuroradiology, 31/6. (2010) 1139-1147. http://doi.org/10.3174/ajnr.A2023

[3] Alderazi Y. J., Shastri D., Kass-Hout T., Prestigiacomo C. J., Gandhi C. D.: Flow diverters for intracranial aneurysms. Stroke Research and Treatment, 2014. 1-12.

http://doi.org/10.1155/2014/415653

[4] Asztalos L., Nagy P., Bognár E., Szikora I.: Pattern Change of Flow Diverters due to Bending. Journal of Biomechanical Engineering and Biosciences, 4. (2017) 19-22.

[5] Fu W., Xia Q.: Interaction between flow diverter and parent artery of intracranial aneurysm: a computational study. Applied Bionics and Biomechanics, 1. (2017) 1-9. http://doi.org/10.1155/2017/3751202

[6] Ugron Á., Paál Gy.: On the boundary conditions of cerebral aneurysm simulations. Periodica Polytechnica Mechanical Engineering, 58/1. (2014) $37-45$. http://doi.org/10.3311/PPme.7392

[7] Závodszky G., Csippa B., Paál Gy., Szikora I.: A novel virtual flow diverter implantation method with realistic deployment mechanics and validated force response. International Journal of Numerical Methods in Biomedical Engineering, 36/6. (2020) e3340.

http://doi.org/10.1002/cnm.3340 